\title{
Micro-morphological studies in some species of Dichanthium Willemet (Poaceae) from Maharashtra, India
}

Shaikh T. J. \& Potdar G. G.*

Department of Botany, Yashwantrao Chavan College of Science, Karad, India.

Received: 3/12/2018; Accepted: 3/21/2018

\begin{abstract}
The present study was carried out to determine the micro-morphology of some species of Dichanthium Willemet (Poaceae) from Maharashtra. Species of Dichanthium were collected from the different localities of Maharashtra for detailed micro-morphological study. Epidermal studies pertains to epidermal cell size, presence and absence of micro-hairs, papillae, its types of silica bodies of species of Dichanthium. All the 7 studied members show the variation in the types and arrangement of the epidermal cells of leaf.
\end{abstract}

Key words: Dichanthium, Leaf, Maharashtra, Micro-morphology, Photomicrograph, Poaceae.

\section{Introduction}

Grasses belong to the family Poaceae consist of approximately 10,000 species and 785 genera (Yanis et al., 2010; The plant list, 2010; Hilu, 2006). The grass family is one of the largest of all plant families. Poaceae is the fifth most species rich flowering plant family (Tim, 1999). It ranged among the top five families of flowering plants in terms of the number of species, but they are clearly the most abundant and important family of the earth's flora (Campbell, 2014). Grasses are distributed worldwide and exhibited great variations in size and shape. Before the later part of the 19th century, taxonomists were confined to the use of the features of reproductive organs as floral characters were considered to provide the most valuable characters to taxonomic affinities (Nwokeocha, 1996). Leaf epidermal studies have proved to be very important in providing information of taxonomic importance. Leaf epidermis study provides valuable data regarding the identification of grasses and is recognized as a source of useful taxonomic characters, because of variations in leaf characters that are taxonomically useful (Barkworth, 1981). The leaf is the most widely used in plant taxonomy (Stace, 1984). Strivastava (1978) described the leaf epidermis as the second most important character after cytology for solving taxonomic problems. Metcalfe (1960) has described comprehensive general account of anatomy and micro-morphology for Poaceae members; also leaf anatomy for tribe Eragrosteae was studied in particular by Renvoize (1983). Earlier, Significance of microhairs as known from the work of Amarshinghe and Watson (1990). The present paper on micro-morphological studies of leaf epidermis is useful in evaluation of the patterns of anatomical variations in epidermis for species

\section{*Corresponding Author:}

Dr. Potdar Girish Gajanan, M.Sc. Ph.D. FIAAT

Assistant Professor, Department of Botany,

Yashwantrao Chavan College of Science, Karad,

Vidyanagar, Dist. Satara 415124.

Maharashtra, INDIA.

E-mail: girishpotdar@gmail.com identification, classification and also in establishing the taxonomic relationships between the seven species of Dichanthium.

\section{Materials and Methods}

Species of Dichanthium were collected from the different localities of Maharashtra for detailed micro-morphological study. Herbarium specimens are deposited in YCCSK herbarium (Department of Botany, Department of Botany, Yashwantrao Chavan College of Science, Karad, Dist. Satara, Maharashtra, India).

For micro-morphological study, the fresh and dried leaves were used throughout preparation. The leaves were boiled in 1:5 conc. $\mathrm{H}_{2} \mathrm{SO}_{4}$ with few crystals of Potassium Dichromate in test tube. After washing with Distilled Water, the peels were made by scraping pieces of treated leaves with the help of safety razor blade; the samples were stained with saffranin and mounted in glycerine (S. Suryanarayana \& N. Krishnaswamy, 1948). Individual cells were identified and measured by micrometer. 20-25; peels were made from each species from several dozen of leaves. All peels were examined and the representative areas were photographed using Olympus research microscope, with $40 \times$ objective and measurements of different cells are taken.

\section{Results}

The species wise details of the epidermal complex and epidermal ornamentation are as under:

1. Dichanthium annulatum (Forssk.) Stapf

The amphistomatic type of leaf is present in $D$. annulatum. Stomata of upper and lower epidermis usually in a single row interrupted by the inter-

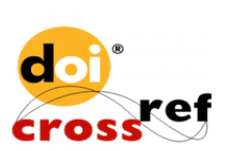


stomatal or epidermal cells, unequal in length to the inter-stomatal cells, subsidiary cells usually with elongated concave ends towards stomata.

\section{Adaxial Surface: \\ Narrowly oblong shaped long cells were observed in upper surface of $D$. annulatum with approx width $140 \times 20 \mu \mathrm{m}$, the long cells with regularly sinuous walled, sparsely papillate, contiguous with single papillae on each cell. The exodermic small papillae have $15 \times 20 \mu \mathrm{m}$ in diameter. The short cells were absent from inter-coastal zone and it's observed in Coastal zone and measured about $5 \times 20 \mu \mathrm{m}$. The Prickle hairs were measured approx $10 \times 20 \mu \mathrm{m}$. Silica bodies Dumbbell Long Shank shaped with 23 $\times 15 \mu \mathrm{m}$. Micro-hairs usually bicellular type, slender with the apical cell $35 \mu \mathrm{m}$ which is shorter than the basal cell $40 \mu \mathrm{m}$ in length. Stomata from upper surface were measured about $35 \times 20 \mu \mathrm{m}$. The inter-stomatal cell is irregularly present and having $80 \times 25 \mu \mathrm{m}$. The epidermal cells were measured about $50 \times 30 \mu \mathrm{m}$ diameter.}

\section{Abaxial Surface:}

Narrowly oblong shaped long cells were observed in lower surface of $D$. annulatum with approx width $220 \times 12 \mu \mathrm{m}$, the long cells with regularly sinuous walled, non papillate. The short cells were absent from coastal zone while observed in inter-coastal zone and measured about $5 \times 7 \mu \mathrm{m}$. The Prickle hairs were measured approx $41 \mu \mathrm{m}$ in length. Silica bodies Dumbbell Short Shank shaped with $26 \times 12$ $\mu \mathrm{m}$. Micro-hairs usually bicellular type with the slender apical cell having $30 \mu \mathrm{m}$ in length which is shorter than the basal cell. The basal cell was measured about $50 \mu \mathrm{m}$ in length. Stomata were measured about $30 \times 20 \mu \mathrm{m}$. The inter-stomatal cell is regularly present between two adjacent stomata with $40 \times 20 \mu \mathrm{m}$. The epidermal cells were measured about $50 \times 30 \mu \mathrm{m}$ in diameter.

\section{Dichanthium armatum (Hook.f.) Blatt. \& Mc} Cann.

Amphistomatic type of leaf is present in D. armatum. Stomata of upper and lower epidermis usually in a single row interrupted by the inter-stomatal or epidermal cells, unequal in length to the interstomatal cells, subsidiary cells usually with elongated concave ends towards stomata.

\section{Adaxial Surface:}

Narrowly oblong shaped long cells were observed in upper surface of $D$. armatum with approx width $70 \times 10 \mu \mathrm{m}$ in length, the long cells with regularly sinuous walled, sparsely papillate. Long cells were interrupted by Short cells. The small exodermic papillae present on long cell, having diameters $15 \times$ $10 \mu \mathrm{m}$. Long cell having more than 5 papillae on each long cell. The short cells were present in coastal zone and it's also observed in inter-coastal and measured about $7.5 \times 7.5 \mu \mathrm{m}$. The Prickle hairs were measured approx $\times \mu \mathrm{m}$ length. Silica bodies with Dumbbell Nodular shaped measured $15 \times 7.5$ $\mu \mathrm{m}$. The Micro-hairs usually bicellular type having slender apical cell and broad basal cell with $20 \mu \mathrm{m}$ in length. Stomata were measures about $20 \times 15 \mu \mathrm{m}$ from upper surface. The inter-stomatal cell is irregularly present with $50 \times 20 \mu \mathrm{m}$. The epidermal cells were measured about $85 \times 30 \mu \mathrm{m}$ diameter.

\section{Abaxial Surface:}

Narrowly oblong shaped long cells were observed in lower surface of $D$. armatum with approx $120 \times$ $10 \mu \mathrm{m}$ in measurement. The long cells with regularly sinuous walled and sparsely papillate. More than 5 exodermic papillae with $5 \times 5 \mu \mathrm{m}$ in diameter present on each Long cell. The long cells were interrupted by Short cells. The short cells were present in intercostals zone and it's also observed in Coastal zone which is measured about $5 \times 10 \mu \mathrm{m}$. Prickle hairs were measured approx $55 \mu \mathrm{m}$ in length. Silica bodies with Regular complex Dumbbell shaped having $15 \times 10 \mu \mathrm{m}$ in measurement. Micro-hairs usually bicellular with slender apical cell $30 \mu \mathrm{m}$ and globular basal cell 30 $\mu \mathrm{m}$ in length. Stomata were measures about $27 \times 22$ $\mu \mathrm{m}$. The inter-stomatal cell is irregularly present with $50 \times 25 \mu \mathrm{m}$. The epidermal cells were measured about $120 \times 20 \mu \mathrm{m}$ diameter.

\section{Dichanthium caricosum (L.) A Camus}

The amphistomatic type of leaf is present in $D$. caricosum. Stomata of upper and lower epidermis usually in a single row interrupted by the interstomatal or epidermal cells, unequal in length to the inter-stomatal cells, subsidiary cells usually with elongated concave ends towards stomata.

\section{Adaxial Surface:}

Broadly oblong shaped long cells was observed in upper surface of $D$. caricosum with approx length 100 $\times 10 \mu \mathrm{m}$, the long cells with regularly sinuous walled, non papillate. Long cells were interrupted by Short cells. The short cells were present in coastal zone and it's also observed in inter-coastal zone which measured about $5 \times 12 \mu \mathrm{m}$. The Prickle hair was measured approx $30 \mu \mathrm{m}$. Silica bodies Dumbbell short shank shaped with $21 \times 15 \mu \mathrm{m}$. Micro-hairs usually bicellular type having slender apical cell measured about $30 \mu \mathrm{m}$ and basal cell with $20 \mu \mathrm{m}$ in length. Stomata were measures about 27.5 $\times 15 \mu \mathrm{m}$. The inter-stomatal cell is regularly present between two adjacent Stomata with $60 \times 23 \mu \mathrm{m}$. The epidermal cells were measured about $55 \times 30$ $\mu \mathrm{m}$ diameter.

\section{Abaxial Surface:}

Narrowly oblong shaped long cells were observed in lower surface of $D$. caricosum with measured about $70 \times 12.5 \mu \mathrm{m}$. The long cells with regularly sinuous walled, non papillate, which is interrupted by Short cells. The short cells were present in coastal zone and it's also observed in inter-coastal zone and measured about $5 \times 10 \mu \mathrm{m}$. Prickle hairs were 
measured approx $45 \mu \mathrm{m}$. Silica bodies with Dumbbell short shank shaped with $27 \times 14 \mu \mathrm{m}$. The Micro-hairs usually bicellular type having apical slender cell having $15 \mu \mathrm{m}$ in length and basal cell with $20 \mu \mathrm{m}$ in length. Stomata were measures about $27 \times 22 \mu \mathrm{m}$. The inter-stomatal cell is regularly present between two adjacent Stomata with $59 \times 24$ $\mu \mathrm{m}$. The epidermal cells were measured about $55 \times$ $15 \mu \mathrm{m}$ diameter.

\section{Dichanthium oliganthum (Hochst. ex Steud.) Cope}

The hypostomatic type of leaf is present in $D$. oliganthum. Stomata of lower epidermis usually in a single row interrupted by the inter-stomatal cells, unequal in length to the inter-stomatal cells, subsidiary cells usually with elongated concave ends towards stomata.

\section{Adaxial Surface:}

Broadly oblong shaped long cells was observed in upper surface of $D$. oliganthum with $110 \times 20 \mu \mathrm{m}$ in measurement, the long cells with regularly sinuous walled, non papillate and interrupted by Short cells. The short cells were present in coastal zone and it's also observed in inter-coastal zone and measured about $10 \times 13 \mu \mathrm{m}$. The Prickle hairs were measured approx $130 \mu \mathrm{m}$. Silica bodies Dumbbell short shank shaped with $20 \times 15 \mu \mathrm{m}$. The Micro-hairs usually unicellular type, slender with $90 \mu \mathrm{m}$ in length. Stomata and inter-stomatal cells were absent from upper surface of $D$. oliganthum. The epidermal cells were measured about 70 x $40 \mu \mathrm{m}$ diameter.

\begin{abstract}
Abaxial Surface:
Narrowly oblong shaped long cells were observed on lower surface of $D$. oliganthum with $90 \times 10 \mu \mathrm{m}$ in measurement, the long cells with regularly sinuous walled, sparsely papillate and interrupted by Short cells. The exodermic small papillae having diameter $7 \times 7 \mu \mathrm{m}$. Each long cell with more than 5 papillae. The short cells were present in coastal zone and it's also observed in inter-coastal zone and measured about $5 \times 16 \mu \mathrm{m}$. Prickle hairs were measured approx $180 \mu \mathrm{m}$. The Silica bodies with Dumbbell short shank shaped structure in with 16 $\times 10 \mu \mathrm{m}$. The Micro-hairs usually slender and bicellular type cells which having $25 \mu \mathrm{m}$ in length. Stomata were measures about $30 \times 20 \mu \mathrm{m}$. The inter-stomatal cell is regularly present between two adjacent Stomata with $40 \times 25 \mu \mathrm{m}$. The epidermal cells were measured about $50 \times 20 \mu \mathrm{m}$ diameter.
\end{abstract}

\section{Dichanthium panchganiense Blatt. \& McCann.}

The amphistomatic type of leaf is present in $D$. panchganiense. Stomata of lower and upper epidermis usually in a single row with irregularly interrupted by the inter-stomatal cells which is unequal in length to the stomatal cell. Subsidiary cells usually having elongated concave ends towards stomata.

\section{Adaxial Surface:}

Broadly oblong shaped long cells was observed in upper surface of D. panchganiense with approx $70 \times$ $20 \mu \mathrm{m}$, the long cells with regularly sinuous walled, sparsely papillate, interrupted by Short cells. The exodermic papillae $2.5 \times 3 \mu \mathrm{m}$, with more than 4 papillae on each long cell. The short cells were present in coastal zone and it's also observed in inter-coastal zone and measured about $5 \times 6 \mu \mathrm{m}$. Prickle hairs were measured approx $27.5 \mu \mathrm{m}$. Silica bodies Dumbbell nodular shaped with $13 \times 10 \mu \mathrm{m}$. Micro-hair usually bicellular type, broad apical cell having $5 \mu \mathrm{m}$ in length and basal cell with $15 \mu \mathrm{m}$ in length. Stomata were measures about $25 \times 15 \mu \mathrm{m}$. The inter-stomatal cell is regularly present between each adjacent Stomata with $22 \times 15 \mu \mathrm{m}$. The epidermal cells were measured about $50 \times 15 \mu \mathrm{m}$ diameter

\section{Abaxial Surface:}

Narrowly oblong shaped long cells were observed on lower surface of $D$. panchganiense with approx width $125 \times 20 \mu \mathrm{m}$ and interrupted by Short cells. The long cells with regularly sinuous walled, sparsely papillate. The exodermic papillae having 7 $\times 10 \mu \mathrm{m}$ in diameter, more than 5 papillae is present on each long cell. The short cells were present in coastal zone and it's also observed in inter-coastal zone and measured about $5 \times 10 \mu \mathrm{m}$. Prickle hairs were measured approx $25 \mu \mathrm{m}$. Silica bodies with Dumbbell nodular shaped measured about $22 \times 7.5 \mu \mathrm{m}$. Micro-hairs usually bicellular type with slender cells having $15 \mu \mathrm{m}$ in length. Stomata were measures about $22.5 \times 16 \mu \mathrm{m}$. The inter-stomatal cell is regularly present between two adjacent Stomata with $45 \times 15.2 \mu \mathrm{m}$. The epidermal cells were measured about $50 \times 15 \mu \mathrm{m}$ diameter.

\section{Dichanthium pertusum (L.) Clayton}

The amphistomatic type of leaf is present in $D$. pertusum. Stomata of lower and upper epidermis usually in a single row with regularly interrupted by the inter-stomatal cells which is unequal in length to the stomatal cell, Subsidiary cells usually having elongated concave ends towards stomata.

\section{Adaxial Surface:}

Broadly oblong shaped long cells was observed in upper surface of $D$. pertusum with approximately measured about $120 \times 10 \mu \mathrm{m}$, the long cells with regularly sinuous walled, non papillate and irregularly interrupted by Short cells. The short cells were present in coastal zone and it's also observed in inter-coastal zone and measured about $5 \times 10$ $\mu \mathrm{m}$. Prickle hairs were measured approximately 70 $\mu \mathrm{m}$. Silica bodies Dumbbell short shank shaped measured about $20 \times 12 \mu \mathrm{m}$. Micro-hair usually bicellular type, apical cell having $5 \mu \mathrm{m}$ in length and basal cell with $20 \mu \mathrm{m}$ in length. Stomata were measures about $25 \times 20 \mu \mathrm{m}$. The inter-stomatal cell is regularly present between two adjacent Stomata 
with $40 \times 20 \mu \mathrm{m}$. The epidermal cells were measured about $40 \times 30 \mu \mathrm{m}$ diameter

\begin{abstract}
Abaxial Surface:
Narrowly oblong shaped long cells was observed in lower surface of $D$. pertusum with approximately measured about $85 \times 10 \mu \mathrm{m}$, the long cells with regularly sinuous walled, non papillate and irregularly interrupted by Short cells. The short cells were present in coastal zone of lower surface, measured about $5 \times 15 \mu \mathrm{m}$. Prickle hair was measured approximately $35 \mu \mathrm{m}$. Silica bodies cross thik shank shaped and measured about $25 \times 15 \mu \mathrm{m}$. Micro-hair usually bicellular type, broad apical cell having $17 \mu \mathrm{m}$ in length and basal cell with $23 \mu \mathrm{m}$ in length. Stomata were measures about $30 \times 20 \mu \mathrm{m}$. The inter-stomatal cell is irregularly present between two adjacent Stomata with $70 \times 25 \mu \mathrm{m}$. The epidermal cells were measured about $40 \times 15 \mu \mathrm{m}$ diameter.
\end{abstract}

\section{Dichanthium tuberculatum (Hack.) Cope}

The amphistomatic type of leaf is present in $D$. tuberculatum. Stomata of lower and upper epidermis usually in a single row with regularly interrupted by the inter-stomatal cells which is unequal in length to the stomatal cell, Subsidiary cells usually having elongated concave ends towards stomata.

\section{Adaxial Surface:}

Broadly oblong shaped long cells was observed in upper surface of $D$. tuberculatum with approximately measured about $90 \times 15 \mu \mathrm{m}$, the long cells with regularly sinuous walled, non papillate and regularly interrupted by Short cells. The short cells were present in coastal zone and measured about $5 \times 15$ $\mu \mathrm{m}$. Prickle hairs were measured approximately 51 $\mu \mathrm{m}$. Silica bodies cross thick shank shaped which is measured about $20 \times 15 \mu \mathrm{m}$. Micro-hair usually bicellular type, apical cell having $15 \mu \mathrm{m}$ in length and basal cell with $35 \mu \mathrm{m}$ in length. Stomata were measures about $30 \times 20 \mu \mathrm{m}$. The inter-stomatal cell is regularly present between two adjacent Stomata with $50 \times 25 \mu \mathrm{m}$. The epidermal cells were measured about $40 \times 30 \mu \mathrm{m}$ diameter.

\section{Abaxial Surface:}

Narrowly oblong shaped long cells was observed in lower surface with approximately measured about $120 \times 10 \mu \mathrm{m}$, the long cells with regularly sinuous walled, non papillate and regularly interrupted by Short cells. The short cells were present in coastal as well as in inter-coastal zone of lower surface, measured about $11 \times 10 \mu \mathrm{m}$. Prickle hair was measured approximately $48 \mu \mathrm{m}$. Silica bodies Dumbbell short shank shaped and measured about $20 \times 10 \mu \mathrm{m}$. Micro-hair usually bicellular type, broad apical cell having $25 \mu \mathrm{m}$ in length and basal cell with $35 \mu \mathrm{m}$ in length. Stomata were measures about $30 \times 23 \mu \mathrm{m}$. The inter-stomatal cell is irregularly present between two adjacent Stomata with $49 \times 20 \mu \mathrm{m}$. The epidermal cells were measured about $75 \times 15 \mu \mathrm{m}$ diameter.

Table 1: Comparative micro-morphology of seven members of Dichanthium.

\begin{tabular}{|c|c|c|c|c|c|c|c|c|c|c|}
\hline $\begin{array}{l}\text { Species } \\
\text { Name }\end{array}$ & $\begin{array}{c}\text { Leaf } \\
\text { Surface }\end{array}$ & $\begin{array}{c}\text { Long } \\
\text { cell } \\
(\mu \mathrm{m}) \\
\end{array}$ & $\begin{array}{c}\text { Short } \\
\text { cell } \\
(\mu \mathrm{m}) \\
\end{array}$ & $\begin{array}{c}\text { Stomata } \\
(\mu \mathrm{m})\end{array}$ & $\begin{array}{c}\text { Micro } \\
\text { hair } \\
(\mu \mathrm{m})\end{array}$ & $\begin{array}{c}\begin{array}{c}\text { Prickle } \\
\text { hairs } \\
(\mu \mathrm{m})\end{array} \\
\end{array}$ & $\begin{array}{c}\text { Silica } \\
\text { Bodies } \\
(\mu \mathrm{m})\end{array}$ & $\begin{array}{c}\text { Inter - } \\
\text { Stomatal } \\
\text { Cell }(\mu \mathrm{m})\end{array}$ & $\begin{array}{c}\text { Epidermal } \\
\text { cell }(\mu \mathrm{m})\end{array}$ & $\begin{array}{c}\text { Papillae } \\
(\mu \mathrm{m})\end{array}$ \\
\hline \multirow{2}{*}{$\begin{array}{l}\text { Dichanthium } \\
\text { annulatum }\end{array}$} & US & $\begin{array}{c}140 \times 20 \\
\text { B1 }\end{array}$ & $5 \times 20$ & $35 \times 20$ & 70 & 20 & $\begin{array}{c}23 \times 15 \\
\text { A2 }\end{array}$ & $\begin{array}{c}80 \times 25 \\
\text { B1 }\end{array}$ & $50 \times 30$ & $15 \times 20$ \\
\hline & LS & $\begin{array}{c}220 \times 12 \\
\text { B2 }\end{array}$ & $5 \times 7$ & $30 \times 20$ & 80 & 41 & $\begin{array}{c}26 \times 12 \\
\text { A1 }\end{array}$ & $\begin{array}{c}30 \times 20 \\
\text { B1 }\end{array}$ & $40 \times 20$ & Absent \\
\hline \multirow{2}{*}{$\begin{array}{l}\text { Dichanthium } \\
\text { armatum }\end{array}$} & US & $\begin{array}{c}70 \times 10 \\
\text { B2 }\end{array}$ & $7.5 \times 7.5$ & $20 \times 15$ & 20 & 59 & $\begin{array}{c}15 \times 7.5 \\
\text { A3 }\end{array}$ & $\begin{array}{c}50 \times 20 \\
\text { B1 }\end{array}$ & $85 \times 30$ & $15 \times 20$ \\
\hline & LS & $\begin{array}{c}120 \times 10 \\
\text { B } 2\end{array}$ & $5 \times 10$ & $27 \times 22$ & 60 & 55 & $\begin{array}{c}15 \times 10 \\
\text { A4 }\end{array}$ & $\begin{array}{c}50 \times 25 \\
\text { B1 }\end{array}$ & $120 \times 20$ & $5 \times 5$ \\
\hline \multirow{2}{*}{$\begin{array}{l}\text { Dichanthium } \\
\text { caricosum }\end{array}$} & US & $\begin{array}{c}100 \times 10 \\
\text { B2 }\end{array}$ & $5 \times 12$ & $27.5 \times 15$ & 50 & 30 & $\begin{array}{c}21 \times 15 \\
\text { A1 }\end{array}$ & $\begin{array}{c}60 \times 23 \\
\text { B1 }\end{array}$ & $55 \times 25$ & Absent \\
\hline & LS & $\begin{array}{c}70 \times \\
12.5 \\
\text { B2 }\end{array}$ & $5 \times 10$ & $30 \times 20$ & 35 & 45 & $\begin{array}{c}27 \times 14 \\
\text { A1 }\end{array}$ & $\begin{array}{c}59 \times 24 \\
\text { B1 }\end{array}$ & $55 \times 15$ & Absent \\
\hline \multirow{2}{*}{$\begin{array}{l}\text { Dichanthium } \\
\text { oliganthum }\end{array}$} & US & $\begin{array}{c}110 \times 20 \\
\text { B2 }\end{array}$ & $10 \times 13$ & Absent & 90 & 130 & $\begin{array}{c}20 \times 15 \\
\text { A1 }\end{array}$ & Absent & $70 \times 40$ & Absent \\
\hline & LS & $\begin{array}{c}90 \times 10 \\
\text { B2 }\end{array}$ & $5 \times 16$ & $30 \times 20$ & 25 & 180 & $\begin{array}{c}16 \times 10 \\
\text { A1 }\end{array}$ & $\begin{array}{c}40 \times 25 \\
\text { B1 }\end{array}$ & $50 \times 20$ & $7 \times 7$ \\
\hline \multirow{2}{*}{$\begin{array}{l}\text { Dichanthium } \\
\text { panchganiense }\end{array}$} & US & $\begin{array}{c}70 \times 20 \\
\text { B1 }\end{array}$ & $5 \times 6$ & $25 \times 15$ & 20 & 27.5 & $\begin{array}{c}13 \times 10 \\
\text { A3 }\end{array}$ & $\begin{array}{c}22 \times 15 \\
\text { B1 }\end{array}$ & $60 \times 15$ & $\begin{array}{c}2.5 \times \\
2.5\end{array}$ \\
\hline & LS & $\begin{array}{c}125 \times 20 \\
\text { B2 }\end{array}$ & $5 \times 10$ & $22.5 \times 16$ & 15 & 25 & $\begin{array}{c}22 \times 7.5 \\
\text { A3 }\end{array}$ & $\begin{array}{c}45 \times 15.2 \\
\text { B1 }\end{array}$ & $50 \times 15$ & $7 \times 10$ \\
\hline \multirow{2}{*}{$\begin{array}{l}\text { Dichanthium } \\
\text { pertusum }\end{array}$} & US & $\begin{array}{c}85 \times 10 \\
\text { B2 }\end{array}$ & $5 \times 10$ & $25 \times 20$ & 25 & 70 & $\begin{array}{c}20 \times 12 \\
\text { A1 }\end{array}$ & $\begin{array}{c}40 \times 20 \\
\text { B1 }\end{array}$ & $40 \times 30$ & Absent \\
\hline & LS & $\begin{array}{c}120 \times 10 \\
\text { B2 }\end{array}$ & $5 \times 10$ & $30 \times 20$ & 40 & 35 & $\begin{array}{c}25 \times 15 \\
\text { A5 }\end{array}$ & $\begin{array}{c}70 \times 25 \\
\text { B1 }\end{array}$ & $40 \times 15$ & Absent \\
\hline \multirow{2}{*}{$\begin{array}{l}\text { Dichanthium } \\
\text { tuberculatum }\end{array}$} & US & $\begin{array}{c}90 \times 15 \\
\text { B2 }\end{array}$ & $5 \times 15$ & $30 \times 25$ & 50 & 51 & $\begin{array}{c}20 \times 15 \\
\text { A } 5\end{array}$ & $\begin{array}{c}50 \times 25 \\
\text { B1 }\end{array}$ & $40 \times 30$ & Absent \\
\hline & LS & $\begin{array}{c}120 \times 10 \\
\mathrm{~B} 2\end{array}$ & $11 \times 10$ & $30 \times 23$ & 60 & 48 & $\begin{array}{c}20 \times 10 \\
\mathrm{~A} 1\end{array}$ & $\begin{array}{c}49 \times 20 \\
\text { B1 }\end{array}$ & $75 \times 15$ & Absent \\
\hline
\end{tabular}

US: Upper Surface, LS: Lower Surface; A1: Dumbbell Short Shank, A2: Dumbbell Long Shank, A3: Dumbbell Nodular, A4: Regular

Complex Dumbbell, A5: Cross thick shank; B1: Elongated concave ends, B2: Elongated Sinuous 
Figure 1: Photomicrographs of leaf blade
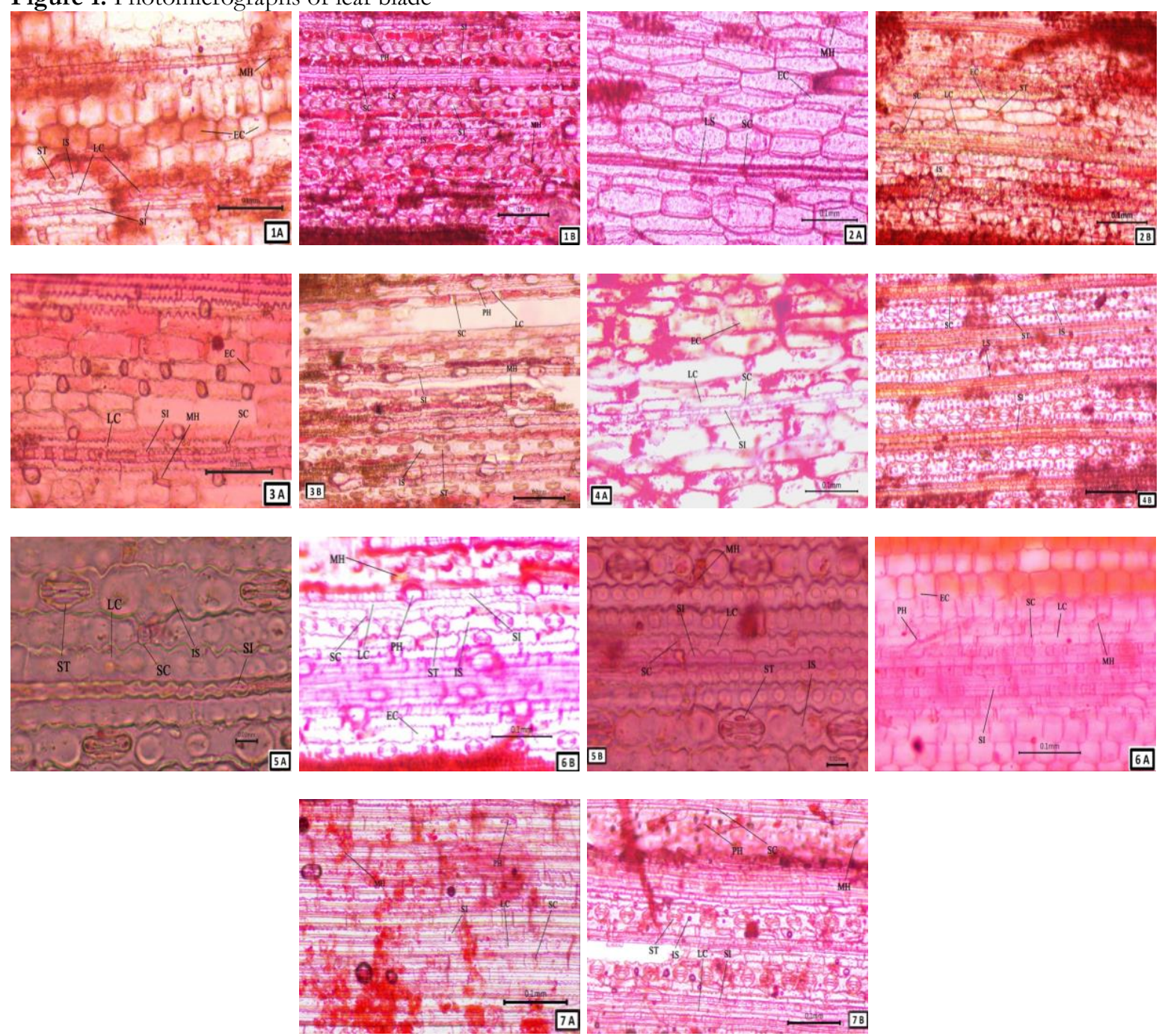

1A. Abaxial surface of D. annulatum showing Microhair, Epidermal cell, Stomata, Silica cells, Long cell and Inter stomatal cell. 1B. Adaxial surface of D. annulatum showing Microhair, Epidermal cell, Stomata, Silica cells, Inter stomatal cell and Long cell. 2A. Abaxial surface of D. armatum showing Epidermal cell, Stomata, Silica cells, and Long cell.

2B. Adaxial surface of D. armatum showing Epidermal cell, Stomata, Silica cells, Long cell, Prickle and Inter stomatal cell.

3A. Abaxial surface of D. caricosum showing Epidermal cell, Stomata, Silica cells, and Long cell.

3B. Adaxial surface of D. caricosum showing Microhair, Epidermal cell, Stomata, Silica cells, Long cell and Inter stomatal cell.

4A. Abaxial surface of D. oliganthum showing Epidermal cell, Silica cells, and Long cell.

4B. Adaxial surface of D. oliganthum showing Stomata, Silica cells, Long cell and Inter stomatal cell.

5A. Abaxial surface of $D$. panchganiense showing Stomata, Silica cells, Long cell and Inter stomatal cell.

5B. Adaxial surface of $D$. panchganiense showing Microhair, Stomata, Silica cells, Long cell and Inter stomatal cell.

6A. Abaxial surface of D. pertusum showing Microhair, Epidermal cell, Stomata, Silica cells and Long cell.

6B. Adaxial surface of D. pertusum showing Microhair, Epidermal cell, Stomata, Silica cells, Long cell and Inter stomatal cell.

7A. Abaxial surface of D. tuberculatum showing Microhair, Silica cells, Prickle hair and Long cell.

7B. Adaxial surface of D. tuberculatum showing Microhair, Stomata, Silica cells, Long cell and Inter stomatal cell.

(Legends. LC: Long cell, SC: Short cell, ST: Stomata, MH: Microhair, PH: Prickle Hair, SI: Silica cell, IS: Inter-stomatal cell, EC:

Epidermal cell, P: Papillae).

\section{Discussion}

Interrelationships of the family Poaceae have been described by Watson et al. (1985) and Clayton (1981). The genus Dichanthium is quite distinct in having a high ratio of basal/distal cell length ratio of bicellular microhairs, and 4-5 long short cells in a row (Faruqi, 1961). Micromorphological features of the leaf surfaces of seven Dichanthium species have a significant value in identification. The long cells were of rectangular and sinuous type in all the members. The short cells mostly alternating with long cells are found in all members. The costal zone shows presence of short cells alternating with silica cells in all species. The measured size of interstomatal cells was variable and were absent in upper surface of $D$. oliganthum. Stomatal nature and stomatal size has been calculated and presented in Tab. 1. 


\section{Conclusion}

The present study on 7 species of Dichanthium reveals that, only $D$. oliganthum showed absence of stomata on upper surface. The size of prickles were larger in $D$. oliganthum than other species. In $D$. annulatum papillae were recorded only on upper surface while in $D$. oliganthum the papillae were recorded only on lower surface of leaf. Papillae were absent in $D$. caricosum, $D$. pertusum and $D$. tuberculatum. Cork cells showed the silica deposition of Dumbbell shapes in all seven Dichanthium species.

\section{Acknowledgements}

The authors is thankful to Science \& Engineering Research Board, a statutory body of Department of Science \& Technology (DST), Government of India for financial assistance under Extra Mural Research Scheme (File No. EMR/2016/003839) to GGP. We are thankful to Principal, Yashwantrao Chavan College of Science, Karad for providing laboratory facilities.

\section{References}

1. Amarasinghe $\mathrm{V}$ and Watson L. Taxonomic Singnificance of Microhair Morphology in the Genus Eragrostis Beauv. (Poaceae). Taxon, 39.1 (1990): 59-65.

2. Barkworth ME. Foliar epidermis and taxonomy of North America Stipeae (Gramineae). Syst. Bot., 6.2 (1981): 136-152.

3. Clayton WD. Evolution and distribution of Grasses. Ann Missouri Bot Gard, 68 (1981): 5-14.

4. Faruqi SA. Studies of leaf epidermis in Botbriocbloa, Capillipedium and Dichanthium. Proceeding of Oklahoma Academy of Sciences, 42 (1961): 26-30.

5. Hilu KW. Skewed distribution of species number in grass genera, is it a taxonomic artifact? In: Trevor Hodkinson, John Parnell and Steve Waldren (Eds.), Towards the Tree of Life, the taxonomy and systematics of large and species rich groups, CRC Press. (2006).
6. Metcalfe CR. Anatomy of the Monocotyledons I Gramineae, Oxford University Press, London. (1960): $1-711$.

7. Nwokeocha CC. Foliar epidermal studies in Oryza punctate. Nig. J. Bot, 9 (1996): 49 -58b.

8. Renvoize SA. A survey of leaf blade anatomy in grasses. I. Andropogoneae. Kew Bull., 37 (1983): 315321.

9. Stace CA. The taxonomic importance of the leaf surface, current concept in plant. Taxonomy systematic association, Academic press, London and Orlando, 25 (1984): 628 - 642.

10. Strivastava AK. Study of leaf epidermis in the genus (Gramineae). Journal of Indian Botanical society, 37 (1978) $155-160$.

11. Suryanarayana S. and Krishnaswamy N. An easy method of obtaining epidermal peels of grass leaves. Current Science, 17.5 (1948): 151.

12. The Plant List, Poaceae, Version 1, Royal botanic Gardens, Kew and Missouri Botanical Garden, Available online at http://www.theplantlist, (2010).

13. Tim M. Puzzled by Poaceae? A Grass Identification Workshop, WSU Mount Vernon Washington State Weed Conference, http://www.pdflibrary.org/pdf/ puzzled-by-poaceae (1999).

14. Watson L, Clifford HT and Dallwitz MJ. The classification of Poaceae, Subfamilies and Supertribes. Aus Jr Bot., 33 (1985): 433-484.

15. Yanis BH, Anthony GV, Vincent $\mathrm{S}$ and Trevor RH, Biogeography of the grasses (Poaceae): a phylogenetic approach to reveal evolutionary history in geographical space and geological time. Botanical Journal of the Linnean Society, 162.4 (2010): 543-557.

\section{Cite this article as:}

Shaikh T. J. \& Potdar G. G. Micro-morphological studies in some species of Dichanthium Willemet (Poaceae) from Maharashtra, India. Annals of Plant Sciences 7.4 (2018) pp. 2150-2155.

d. http://dx.doi.org/10.21746/aps.2018.7.4.13

Source of support: Department of Science \& Technology (DST), Government of India

\author{
Conflict of interest: $\mathrm{Ni}$
}

